\title{
Umbral, Francisco, Treinta cuentos y una balada, Edición de Bénédicte de Buron- Brun, Sevilla, Editorial Renacimiento, 2018, 260 pp.
}

Marina Casado

Universidad Complutense de Madrid, España

\author{
Este poema en prosa es la historia \\ de un poema que nunca llegaré a escribir. \\ Francisco Umbral en "Jeanette de Marbella"
}

Francisco Umbral jamás fue un poeta en el estricto sentido de la palabra -aunque publicó algún poemarioy, sin embargo, toda su prosa está perfumada de lírica: los artículos, las memorias, las novelas en las que su propia figura deambula entre las páginas, literaturizada, hecha personaje de sangre y de mentiras, a partes iguales. También fue lírico en su faceta de cuentista. La profesora Bénédicte de Buron-Brun, que ha dedicado gran parte de su vida al análisis y la investigación de la obra umbraliana, ha publicado recientemente un libro que desvela nuevos y desconocidos matices del autor en este ámbito menos estudiado. Treinta cuentos y una balada (Renacimiento, 2018) constituye una recopilación de treinta y un textos inéditos inscritos en el género del cuento cuyo mayor valor reside, además de en la exquisita elaboración estilística que siempre acompaña la literatura de Umbral, en el hibridismo que presenta y en el carácter documental de la realidad histórica y social española.

Como señala la propia editora en su estudio preliminar, se trata de una obra de interés no solo para amantes de la literatura, sino también para sociólogos e historiadores. Umbral, con su pluma elegante y amena, va conduciendo al lector por los vericuetos de la realidad española desde la perspectiva de personajes muy variados, desde los señoritos decimonónicos del relato que abre el libro, "Descubrimiento del Mediterráneo", hasta el muchacho pueblerino que trata desesperadamente de contagiarse del espíritu hippie sesentero en "Ye-yé". Sus cuentos alcanzan la Transición y se burlan de ella, como en "El ángel, la mula y el buey. Cuento de Navidad", un texto curioso e imprevisible en clave paródica en el que aparecen ángeles trostkistas y bueyes y pastorcillos de Comisiones Obreras, además de un Fraga "disfrazado de Rey Baltasar" y otras hilarantes extravagancias. El autor demuestra su habilidad para introducir la Historia con naturalidad y elocuencia, sin que resulte abrupta su incursión. Por ejemplo, en "Los helechos arborescentes" -cuento que acabaría desembocando en una de sus más célebres novelas-, está relatando las visitas de los protagonistas a un burdel y contextualiza así la época: "Fuimos unas cuantas veces mientras Franco ganaba la guerra, tomaba Bilbao, rechazaba las ofertas de paz y entre Azaña y Alberti trataban de salvar el Museo del Prado". En una simple frase -puesta en boca de un niño- resume el ambiente bélico y hace un guiño también al literario, citando a Rafael Alberti. No es el único escritor que desfila por las páginas del libro. A lo largo de los treinta y un cuentos se refiere a figuras nacionales como Pablo Neruda, Miguel Hernández, Jorge Manrique, Federico García Lorca o Rubén Darío, y también universales: Henry Miller, Truman Capote, Tenessee Williams, Charles Baudelaire, Edgar Allan Poe, William Blake, Proust, Mallarmé, Nabokov... No deja de lado tampoco a los pintores: Magritte, Chagall, Delacroix, Zurbarán, etc. Es un narrador que no disimula su ingente poso cultural, pero que encuentra el instante y el modo preciso de introducirlo.

Este narrador, en algunos cuentos, se parece sospechosamente a sí mismo. En "Se me muere el coche ¿o el perro?", se menciona que es periodista y escribe artículos. En "La traductora”, es escritor e incluso se refieren a él como "don Francisco". No cabe duda de que Umbral no resistió la tentación de inmiscuirse en su propia obra literaria, como lo haría en su prosa periodística y novelística. Sin embargo, no se cierra a esta perspectiva. En otros cuentos, adopta valientemente papeles muy diferentes, como el gitano malhablado de "Crista, verso y prosa", el suicida de "Una manera de morir" o el psicópata homicida de "Un carnívoro cuchillo". Decenas 
de personajes diversos, rutinarios o extravagantes, jóvenes o maduros, humildes y acomodados, se perfilan a lo largo del libro, dibujando treinta y una miradas distintas, treinta y una caras del mismo escritor que es capaz de proyectar múltiples voces.

Él mismo busca ese contraste, esa diversidad, también en los propios argumentos, en el choque entre clases sociales, que reverbera en cuentos como "Los que no fuimos de veraneo" -en el que un adolescente de familia humilde sufre su pena de amor por Teresita, una vecina perteneciente a la alta burguesía- o "La noche de las doncellas" -aquí, unas criadas se visten a escondidas con ropajes pertenecientes a sus señores-. También desde esta perspectiva sociológica merece la pena destacar la importancia que atribuye en sus historias a la llegada del turismo a partir de la época aperturista de los sesenta, dando lugar a exóticos y atractivos personajes femeninos como "la yanqui" o "Jeanette de Marbella". Como antítesis aparece "la madrileña", entrañable y castiza, a medio camino entre la dominación y la vulnerabilidad.

El hibridismo umbraliano recorre personajes, perspectivas, estilos. En unos cuentos es el Umbral más canalla - "Crista, verso y prosa"-, en otros llega al límite del humor más negro -"Los adúlteros"-. La estructura cuasi teatral, con los diálogos como protagonistas, surge en "El vaivén y el humo" y "Un muerto en el semáforo". También aparece el poeta con las alas desplegadas: "Jeanette de Marbella" constituye un hermoso poema en prosa, como él mismo reconoce en el texto, con un estribillo que redunda y va marcando un ritmo constante, igual que la marea: "Pero viene el mar y me dice que no y no". La "balada" final a Jesse James, homenaje a la infancia, tiene también mucho de lírica, comenzando por el título. En esta faceta más poética, destaca "El arcángel San Gabriel pestañas postizas", una curiosa narración de tintes eróticos en la que desarrolla un trasvase de lo pagano a lo religioso, a la manera de Rafael Alberti. De ese modo, el personaje amado por el protagonista comercia con su sexualidad, pero es identificado por éste con el arcángel San Gabriel -célebre por su ambigüedad sexual- y con Santa Catalina. Se refiere a él como "Venus de espumas industriales", en un alarde metafórico que lo conecta con el movimiento futurista.

Las metáforas, de hecho, resultan determinantes en el estilo literario umbraliano, precisas e ingeniosas: "La gran flor de la música", "Sus manecitas eran como rosadas mariposas volándoles el rostro", "Las familias se reunían en asociaciones madrepóricas y coralíferas para la hora inminente de la comida en el merendero". La influencia de Ramón Gómez de la Serna, con su fondo sombrío, se dibuja en muchas de las imágenes, que podrían considerarse auténticas greguerías: "Su frialdad de reptiles sagrados y muertos" (refiriéndose a las joyas), "Lo peor de no tener trabajo es que se llega demasiado pronto a todas partes", "A veces el infinito toma forma de una semana", "A los muertos les sobra el tiempo", "Morirse es quedarse mirando fijamente algo, por toda la eternidad".

La muerte se alza como un tema trascendental y constante en los cuentos umbralianos, así como el amor, que florece en múltiples facetas: el primer amor - "Los que no fuimos de veraneo"-, el amor fallido - "Jeanette de Marbella"-, el amor fatal - "Los adúlteros", "Un carnívoro cuchillo", el erotismo - "Crista, verso y prosa”Precisamente esta última faceta, la erótica y sexual -unida, por supuesto, a la política-, provocó que algunos de los cuentos no pasaran la censura. Es innegable y valiosísima, pues, la intención rupturista y transgresora del autor, contextualizada en el franquismo y durante la Transición.

Umbral escribió más de un centenar de cuentos entre 1957 y 2007, por lo que se trata de un ámbito digno de estudio que no ha sido lo suficientemente abordado por la crítica. Ahora, Bénédicte de Buron-Brun ha reunido en este volumen una estimable muestra de él, inédita, bajo criterios cronológicos y temáticos, y precedida de un prólogo enriquecedor que es resultado de una esforzada selección entre los papeles del escritor -con ayuda de su viuda, España Suárez-y de un minucioso estudio. Los amantes de las letras estamos de enhorabuena y, por lo visto, Umbral nunca va a dejar de sorprendernos. 